http://jmscr.igmpublication.org/home/ ISSN (e)-2347-176x ISSN (p) 2455-0450 crossref DOI: https://dx.doi.org/10.18535/jmscr/v9i7.09

\title{
Effectiveness of IASTM (Instrument-Assisted Soft Tissue Mobilization) in the Treatment of Chronic Calf Pain: A Case Study
}

\author{
Authors \\ Dr Keerthika Ranji ${ }^{*}$, Dr Amit Hosur ${ }^{2}$ \\ ${ }^{1}$ Associate Professor, Department of Electrotherapy and Electrodiagnosis, Lokmanya Medical College of \\ Physiotherapy, Kharghar \\ ${ }^{2}$ Associate Professor B.V.V. Sanghas College of Physiotherapy, Bagalkot, Karnataka \\ *Corresponding Author \\ Dr Keerthika Ranji
}

\begin{abstract}
Pain in the calf region is a very common complaint experienced by women. There are a multitude of factors that contribute to calf pain in women. One of the commonest causes is prolonged standing. The purpose of this case study was to demonstrate the use of instrument assisted soft tissue mobilisation in the treatment of chronic calf pain in a 27 year old female dancer. All other causes of calf pain such as venous thrombosis, skeletal abnormalities, limb length discrepancy, etc were ruled out. The Egde tool was used for the treatment and brushing strokes were performed. The patient showed significant improvement after 10 sessions

Keywords: Edge tool, instrument assisted soft tissue mobilisation, chronic calf pain.
\end{abstract}

\section{Introduction}

Musculoskeletal pain is a common complaint among women. The most common site of pain is the lower back region ${ }^{(1)}$. Also many women experience pain in both upper and lower limbs due to various conditions ${ }^{(2,3)}$. Another common symptom experienced by women is non specific calf pain ie pain in the calf region although a specific medical condition like varicose veins etcdoes not exist. However not many studies have been conducted to determine the etiology of non specific calf pain and the treatment. Also since it is a self limiting pain; many women do not seek medical aid for the same. However there are several physiotherapeutic interventions which can treat non specific calf pain such as soft tissue mobilisation techniques, massage, exercise programs, ultrasound, transcutaneous electrical stimulation etc ${ }^{(4,5,6)}$. There is a paucity of evidence analysing the effectiveness of the various physiotherapeutic modalities in the treatment of non specific calf pain. Thus this case study was conducted to determine the effectiveness of IASTM using Edge tool.

\section{Case Description}

The patient was a 27 year old female dancer who presented with complaints of vague calf pain in the right lower limb since 2 to 3 years. There was no history of trauma or injury. The onset of pain was gradual and it was a dull ache. The pain aggravated after prolonged walking and when she 
went for dance performances. Gradually her daily activities started getting affected as the pain started increasing in severity thus she sought medical assistance. She underwent thorough examination by a physician followed by investigations to rule out vascular abnormalities, muscle tears, muscle edema, skeletal abnormalities and tumors. She also underwent blood tests which revealed normal blood counts. She was given analgesics by the physician and referred to physiotherapy department.

Thorough examination of the patient was conducted in the physiotherapy department by the Physiotherapist. Assessment of temperature, venous pulse, limb girth, reflexes and sensations showed no abnormality. Proximal joints ie hip, sacroiliac joint and lumbar spine assessment showed no abnormality.

\section{Further Detailed Assessment Revealed Following Impairments}

Pain - VAS 8/10

Tenderness on palpation in right calf

Multiple soft tissue nodular restrictions on palpation

Slight weakness of right plantar flexors

Tightness of right Gastrosoleus

Reduced range of dorsiflexion at right ankle Imaging - Coronal MRI with contrast revealed dense soft tissue abnormality in the right calf.

From the clinical examination and supportive imaging finding it was concluded that the patient had limited soft tissue mobility within the mid region of the right calf. Thus we devised a plan of care consisting of 10 sessions of IASTM using Edge tool combined with stretching exercises.

The primary goals of treatment were to reduce the pain, restore the patient to her previous level of activity and prevent further deterioration

\section{Intervention}

During each treatment session, interventions were applied in the following sequence: a warm-up spot marching for 5 minutes

IASTM - 6-8 minutes of IASTM on the right calf using Edge 2 of the edge tool. Brushing strokes were performed

Stretching exercises for gastrocnemius and soleus Eccentric calf exercises- single leg calf lowers with the right leg, two sets of 15 repetitions each, once daily

Ice pack application for 10 minutes to control inflammation.

\section{Outcome}

The patient was reassessed at the end of 10 sessions. There was complete relief of pain Palpation revealed no tenderness over the right mid calf. The tissue was soft, supple and mobile without any nodule. The strength of right gastrosoleus was 5/5 and the range of motion of ankle dorsiflexion was normal.

\begin{tabular}{|c|c|c|c|c|}
\hline Test measure & Pre treatment & & Post treatment & \\
\hline & Right & Left & Right & Left \\
\hline \multicolumn{5}{|c|}{ Muscle strength (ankle) } \\
\hline Plantar fkexion & $4 / 5$ & $5 / 5$ & $5 / 5$ & $5 / 5$ \\
\hline Dorsiflexion & $5 / 5$ & $5 / 5$ & $5 / 5$ & $5 / 5$ \\
\hline \multirow[t]{2}{*}{ Palpation } & $\begin{array}{l}\text { Severe tenderness in the } \\
\text { mid region of the } \\
\text { gastrocnemius muscle in } \\
\text { the right calf muscle }\end{array}$ & Normal & $\begin{array}{l}\text { The patient reported } \\
\text { no pain during manual } \\
\text { and instrument } \\
\text { assisted palpation. }\end{array}$ & Normal \\
\hline & $\begin{array}{l}\text { Nodular restrictions } \\
\text { detected in the painful } \\
\text { area of the right calf. }\end{array}$ & & $\begin{array}{l}\text { No fibrotic lesions } \\
\text { were detected in the } \\
\text { right calf. }\end{array}$ & \\
\hline Visual analog scale & $8 / 10$ & $0 / 10$ & $0 / 10$ & $0 / 10$ \\
\hline
\end{tabular}




\section{Discussion}

The treatment protocol used in this case showed good results. There was improvement in the symptoms. The patient could return to her active lifestyle and prior functional level including participation in dance performances. Instrument assisted soft tissue mobilisation helped in treatment of the soft tissue restrictions thereby allowing full muscle mobility and lengthening. Though a variety of tools can be used; Edge tool has several advantages thus was chosen in this case.

An array of physiological changes occur due to IASTM. Fibroblasts which are mechanosensitive cells respond to mechanical external loading which occurs with the application of $\operatorname{IASTM}^{(7,8,9)}$. The mechanism underlying the beneficial effects is mechanotransduction which causes tissue repair and remodelling ${ }^{(10)}$.

There is also an increase in the blood flow, interruption of nociceptive input, reduced tissue viscosity, enhanced flexibility and myofascialrelease $^{(11)}$. Evidence also shows that a combination of IASTM and stretching together results in better improvement in flexibility than static stretching alone ${ }^{(12)}$.

\section{Conclusion}

From this case study we can conclude that IASTM is effective in the management of non-specific chronic calf pain. However a combination of stretching with IASTM has a better outcome.

\section{References}

1. To WW, Wong MW. Factors associated with back pain symptoms in pregnancy and the persistence of pain 2 years after pregnancy. Acta Obstet Gynecol Scand 2003;82:1086-91

2. Heckman JD, Sassard R. Musculoskeletal considerations in pregnancy. $J$ Bone Joint Surg Am 1994;76:1720-30

3. Borg-Stein J, Dugan SA, Gruber J. Musculoskeletal aspects of pregnancy. Am J Phys Med Rehabil 2005;84:180-92
4. Ernst E. Manual therapies for pain control: chiropractic and massage. Clin $J$ Pain2004;20:8-12

5. Nnoaham KE, Kumbang J. Transcutaneous electrical nerve stimulation (TENS) for chronic pain. Cochrane Database Syst Rev 2008;(3):CD003222.

6. Mayer F, Hirschmuller A, Muller S, Schuberth M, Baur H. Effects of shortterm treatment strategies over 4 weeks in Achilles tendinopathy. $\mathrm{Br} \quad J \quad$ Sports Med 2007;41:e6

7. Davidson CJ, Ganion LR, Gehlsen GM, Verhoestra B, Roepke JE, Sevier TL. Rat tendon morphologic and functional changes resulting from soft tissue mobilization. Med Sci Sports Exerc 1997;29:313-9

8. Chiquet M, Tunc-Civelek V, SarasaRenedo A. Gene regulation by mechanotransduction in fibroblasts. Appl Physiol Nutr Metab 2007;32:967-73

9. Wang JH, Thampatty BP, Lin JS, Im HJ. Mechanoregulation of gene expression in fibroblasts. Gene 2007;391:1-15

10. Wang JH, Thampatty BP, Lin JS, Im HJ. Mechanoregulation of gene expression in fibroblasts. Gene 2007;391:1-15

11. Matthew L, Rebecca H, Kelly L, Eric H, Russ M, Amber W (2017). The effects of instrument-assisted soft tissue mobilization compared to other interventions on pain and function: a systematic review, Physical Therapy Reviews, 22:1-2, 76-85.

12. Leanna J.G, Jill CS, Brittany M, Steven T.M, Justin M.M, Nicholas J.I, (2019). Instrument-assisted soft tissue mobilization and proprioceptive neuromuscular facilitation techniques improve hamstring flexibility better than static stretching alone: a randomized clinical trial, Journal of Manual \& Manipulative Therapy, 27:1, 15-23. 